\title{
FODDER CROPS AS PROMISING SOURCES OF BIOLOGICALLY ACTIVE COMPOUNDS IN INDUSTRIAL LIVESTOCK BREEDING
}

\section{UPRAWY PASZOWE JAKO OBIECUJACE ŹRÓDŁA BIOLOGICZNIE AKTYWNYCH ZWIAZZKÓW W PRZEMYSŁOWEJ HODOWLI ZWIERZĄT}

Institute of Agriculture and Livestock of the Carpathian region, Lviv, Ukraine

${ }^{1}$ Kharkiv State Zooveterinary Academy, Kharkiv, Ukraine

${ }^{2}$ National University of Pharmacy, Kharkiv, Ukraine

\begin{abstract}
Streszczenie. Oznaczono zawartość izoflawonoidów w zielonej masie wiodących ukraińskich odmian soi, w zależności od stadiów wegetacji, a także obecności wielu związków fenolowych w różnych organach wegetatywnych soi odmiany 'Podilska-1', która jest zalecana do siewu kombinowanego z kukurydzą na kiszonkę. Naukowo uzasadniono wpływ tych związków na zawartość tłuszczu w mleku i właściwości reprodukcyjne krów, co jest zgodne z wynikami wieloletniego stosowania kukurydziano-sojowej kiszonki jako składnika mieszanki paszowej dla wysokowydajnych krów w warunkach całorocznego jednorodnego żywienia w stadzie bydła mlecznego z 1050 krowami.
\end{abstract}

Key words: soybean, isoflavonoids, cows, butter-fat yielding capacity, productivity.

Słowa kluczowe: soja, izoflawonoidy, krowy, zawartość tłuszczu w mleku, wydajność.

\section{INTRODUCTION}

All livestock animals, especially high-producing ones, within conditions of industrial livestock management have high possibility to get stressed, which is up to $20-30 \%$ induced by genetic factors, and up to $70-80 \%$ - by feeding and management conditions. In this case the behavior of animals changes: they become excited, more active, aggressive, have less rest in comfortable conditions, their appetite is decreased and they tend to eat less fodder. This leads to the productivity decrease by $10-20 \%$, while the fodder expense for a product unit increases by the same amount, or even more. The stress situations of livestock are usually avoided by creating more comfortable conditions of their management and biologically complete feeding.

Results of various scientific studies on livestock feeding show that improvement of general physiological state and smoothing the adverse effects of industrial livestock management is possible by using in their diet vitamins and forage, containing natural polyphenolic

Correspondinq author - Adres do korespondencji: Stakh Vovk, Institute of Agriculture in the Carpathian region NAAS, Grushevskogo 5, Obroshyno 81115, Pustomytivs'kyi distr., Lviv region, Ukraine, e-mail: vovkstah@gmail.com 
compounds, such as flavonoids, isoflavonoids along with steroidal compounds, carotenoids, etc, that stimulate the immune system of the animals, show positive effect on their increase in weight, milk productivity and reproduction (Jamroz and Potkanski 2004; Dorszewski 2011).

In Ukraine livestock breeding is in the first place in providing welfare of the population. In such a case the characteristics of quality and costs of production of animal products, which are essential in modern on-the-farm conditions, gain a great importance. Negative ecological and technological factors, being the shadow feature of industrial technologies, cause the increase of requirements to the biological value of diets, effective fodder usage, which leads to the increase of livestock production costs. A number of biologically active compounds (ecdysteroids, flavonoids, etc.) contribute to a more effective bioavailability of diet, and stimulate the immune resistance, adaptability and flexibility of animal body to the extreme factors of industrial management systems: microbiological aggression, lack of sunlight, increased humidity, air pollution, insufficient amount of amino acids, vitamins etc. in the diet.

For many years plant breeders have been creating new highly productive varieties and hybrids of fodder crops. Their detailed study not only by the indices of primary purpose, but also by the content of biologically active compounds that show positive effect on fodder digestibility, body immune system, quantity and quality of production, reproductive function of livestock, is up-to-date since it is of great scientific and practical importance.

Biologically active compounds (BAC) of herbal origin - are a group of compounds of diverse structure and origin, which can increase the processes of protein formation in living organisms, possess antioxidant properties, stimulate synthesis of milk fat and favorably influence the reproductive function of animals (Kulyk et al. 1999). For instance, herbal anabolics are practically non-toxic, are easily eaten and almost lack contraindications. The most important feature of plant anabolics is their ability to increase activity of anabolic systems of animal or human body. Herbal anabolic compounds can increase the organism's tolerance to physical activity, hypoxia, radioactive and electromagnetic emission (Baraboy 1984; Bulanov 1993; Taylor 2002).

The most important fact is that expression of anabolic effect doesn't depend much on the providing animals' diet with proteins. For instance, ecdysteroids of Maral root (Rhaponticum carthamoides (Willd.) Iljin) act by interacting with cell receptors of the nuclei with further initiation of the process of gene transcription responsible for protein synthesis. These compounds also provide the non-specific immune resistance, adaptability and flexibility of animal body towards extreme factors of industrial management systems.

In our previous works we have already informed about the anabolic activity of the extract of soybean extraction cake (Levashova 2002) and the presence of biologically active compounds in the green mass and silage of amaranth which show positive influence on the weight gain and reproductive function of replacement gilts (Tsyhanok et al. 1999), productivity and protective functions of the organism of cows after their feeding with corn and soybean silage, as well as the influence of such silage on the butter-fat yielding capacity of cows. In addition, the green mass of a new feeding crop tyfon was found to contain biologically active compounds able to stimulate animals' productivity (Koch et al. 1987; Zinchenko 2013). Those plant-derived biologically active compounds were found to stimulate the lipid metabolism in calves (Vovk and Pavkovych 2008). 
Since the profound phytochemical study of fodder crops have been previously studied in a limited way, and some biologically active compounds of preferred fodder crops have not been studied at all, the purpose of our study was determination of chemical composition of BAC, their content, in particular steroidal compounds in tyfon green mass, as well as carrying out the search of those compounds in certain organs of soybean of different varieties.

We have set the following tasks:

- to carry out preliminary phytochemical study of qualitative composition of soybean plant material;

- to determine the quantitative content of BAC of phenolic nature in different parts of soybean plant and steroidal compounds of tyfon vegetative mass;

- to define a connection between the presence of the abovementioned groups of BAC in fodder and productive properties of livestock.

\section{MATERIAL AND METHODS}

The objects of our study were the green mass of soybean (Glycine hispida (Moench) Maxim.) and its individual parts - leaves, stems, pods and seeds - of different widely distributed in Ukraine varieties, and leaves and roots of a relatively new fodder culture - tyfon (Brassica campestris f. biennis DC. $\times$ B. rapa L.) - a hybrid of Chinese cabbage and turnip which is not yet widely used as an industrial fodder crop in Ukraine.

General identification tests, paper chromatography and TLC were used for identification of phenolic compounds in different parts of vegetative mass of soybean. The quantitative content of phenolic compounds was determined spectrophotometrically.

The quantitative content of BAC in soy leaves was determined using the following methods: polysaccharides were studied gravimetrically, the sum of carboxylic acids and the sum of oxidazable polyphenols were determined titrimetrically, the quantity of flavonoids, hydroxycinnamic acids, polyphenols calculated on gallic acid, steroidal compounds, carotenoids and chlorophylls a and b was determined spectrophotometrically. Gas chromatography allowed to study the carboxylic acids, steroidal compounds and volatile compounds in details (Zinchenko 2013).

Effectiveness of corn-soybean silage usage as a component of forage mixtures for high-producing cows was studied at the State Enterprise Research Farm "Kutuzivka" in Kharkiv region (Ukraine) using the livestock population of 1050 cows. The record of gross milk yield of the herd and fat content of the milk was kept daily.

The results were statistically verified by calculating the arithmetic mean and standard deviation for the traits.

\section{RESULTS AND DISCUSSION}

Table 1 represents the data on the BAC composition of vegetative organs of soybean of 'Feia', 'Skelia', and 'Podilska-1' varieties. They were found to be rich in phenolic compounds flavonoids, isoflavonoids, hydroxycinnamic acids, and other polyphenols (tannins). Flavonoids (kaempferol, quercetin, astragalin, isoquercetin, rutin, etc.) possess vitamin, antioxidant properties. 
Isoflavonoids (genistein, genistin, formononetin, daidzein, astroside, ononin, etc.) are characterized as anabolics and compounds, that influence the reproductive function of animals. Hydroxycinnamic acids (chlorogenic, neochlorogenic, ferulic, p-coumaric) show antioxidant and antitumor properties.

Table 1. Quantitative content of biologically active compounds (BAC) in the green mass of soybean in the phase of complete seed formation, \% of dry weight

Tabela 1. llościowa zawartość biologicznie aktywnych związków (BAZ) w zielonej masie soi w fazie pełnego wypełnienia kolby ziarnem (uziarnienia), w \% suchej masy

\begin{tabular}{lllcc}
\hline $\begin{array}{l}\text { Biologically active compound } \\
\text { Związek biologicznie aktywny }\end{array}$ & \multicolumn{1}{c}{$\begin{array}{c}\text { Method } \\
\text { Metoda }\end{array}$} & \multicolumn{2}{c}{$\begin{array}{c}\text { Soybean varieties } \\
\text { Odmiana soi }\end{array}$} \\
$\begin{array}{l}\text { Polysaccharides } \\
\text { Polisacharydy }\end{array}$ & $\begin{array}{l}\text { gravimetry } \\
\text { grawimetria }\end{array}$ & $5.94 \pm 0.28$ & $4.53 \pm 0.34$ & $2.32 \pm 0.33$ \\
\hline $\begin{array}{l}\text { permanganatometry } \\
\text { permanganatometria }\end{array}$ & $2.78 \pm 0.18$ & $2.96 \pm 0.25$ & $2.46 \pm 0.29$ \\
\hline $\begin{array}{l}\text { Polyphenols } \\
\text { Polifenole }\end{array}$ & $\begin{array}{l}\text { complexonometry } \\
\text { kompleksonometria }\end{array}$ & $0.53 \pm 0.09$ & $0.49 \pm 0.08$ & $0.42 \pm 0.09$ \\
\hline $\begin{array}{l}\text { spectrophotometry } \\
\text { spektrofotometria }\end{array}$ & $2.55 \pm 0.15$ & $1.00 \pm 0.18$ & $0.97 \pm 0.19$ \\
\hline $\begin{array}{l}\text { Flavonoids } \\
\text { Flawonoidy }\end{array}$ & $\begin{array}{l}\text { spectrophotometry } \\
\text { spektrofotometria }\end{array}$ & $1.92 \pm 0.12$ & $2.90 \pm 0.09$ & $2.10 \pm 0.08$ \\
\hline $\begin{array}{l}\text { Isoflavonoids } \\
\text { Izoflawonoidy }\end{array}$ & $\begin{array}{l}\text { spectrophotometry } \\
\text { spektrofotometria }\end{array}$ & $2.00 \pm 0.15$ & $1.87 \pm 0.11$ & $1.50 \pm 0.10$ \\
\hline $\begin{array}{l}\text { Hydroxycinnamic acids } \\
\text { Kwasy hydroksycynamonowe }\end{array}$ & $\begin{array}{l}\text { spectrophotometry } \\
\text { spektrofotometria }\end{array}$ & $3.00 \pm 0.12$ & $2.30 \pm 0.14$ & $1.50 \pm 0.12$ \\
\hline $\begin{array}{l}\text { Ascorbic acid } \\
\text { Kwas askorbinowy }\end{array}$ & $\begin{array}{l}\text { titrimetry } \\
\text { miareczkowanie }\end{array}$ & $0.05 \pm 0.01$ & $0.06 \pm 0.01$ & $0.06 \pm 0.01$ \\
\hline
\end{tabular}

Some features of determination of abovementioned compounds of soybean are the following: flavonoids show characteristic fluorescence at excitation by ultraviolet and blueviolet emission. Due to this method of luminescent analysis there is a possibility to identify flavonoids in plants, their localization in organs and tissues, as well as an additional test at identity and quality of plant material (fodder) evaluation.

The results of our experiment haven't confirmed the existing idea that in early vegetation stages the content of biologically active compounds is higher comparing to the complete seed filling phase. Only two soybean varieties ('Podilska-1' and 'Feia') had slightly higher content of those compounds in the vegetative mass at the beginning of seed filling phase. In general, the average increase of isoflavonoids content in 8 soybean varieties at the beginning of seed filling and the complete seed filling comparing to the flowering stage comprised $37.4 \%$ and $39.8 \%$ respectively.

The content of isoflavonoids in the vegetative mass of all studied soybean varieties increased with the development stages of plants (Table 2).

We haven't found a straight correlation between the content of proteins and isoflavonoids in the plants either. For instance, in the flowering phase and beginning of seed filling phase the soybean vegetative mass had similar protein content, even slightly lower during the latter, but the quantity of isoflavonoids increased in $37.4 \%$.

The obtained data allow considering the complete seed filling phase as the most suitable one for soybean ensilation since the isoflavonoids content is the highest during this stage. 
Table 2. Content of raw protein and isoflavonoids in the vegetative mass of different soybean varieties by the stages of vegetation (\%, calculated on the dry plant material)

Tabela 2. Zawartość białka surowego i izoflawonoidów w masie wegetatywnej różnych odmian soi w fazach wegetacji (\%, obliczony na suchym materiale roślinnym)

\begin{tabular}{|c|c|c|c|c|c|c|}
\hline \multirow{3}{*}{$\begin{array}{l}\text { Variety } \\
\text { Odmiana }\end{array}$} & \multicolumn{6}{|c|}{$\begin{array}{l}\text { Stage of vegetation } \\
\text { Fazy wegetacji }\end{array}$} \\
\hline & \multicolumn{2}{|c|}{$\begin{array}{l}\text { flowering } \\
\text { kwitnienie }\end{array}$} & \multicolumn{2}{|c|}{$\begin{array}{c}\text { beginning of seed filling } \\
\text { początek wypełnienia nasion }\end{array}$} & \multicolumn{2}{|c|}{$\begin{array}{c}\text { complete seed filling } \\
\text { pełne wypełnienie nasion }\end{array}$} \\
\hline & $\begin{array}{l}\text { protein } \\
\text { białko }\end{array}$ & $\begin{array}{l}\text { isoflavonoids } \\
\text { izoflawony }\end{array}$ & $\begin{array}{c}\text { protein } \\
\text { białko }\end{array}$ & $\begin{array}{l}\text { isoflavonoids } \\
\text { izoflawony }\end{array}$ & $\begin{array}{l}\text { protein } \\
\text { białko }\end{array}$ & $\begin{array}{l}\text { isoflavonoids } \\
\text { izoflawony }\end{array}$ \\
\hline 'Skelia' & 14.60 & 0.77 & 18.25 & 1.50 & 16.65 & 1.52 \\
\hline 'Podilska-1' & 24.32 & 1.50 & 18.02 & 1.81 & 18.21 & 1.76 \\
\hline 'Feia' & 19.21 & 2.01 & 20.68 & 2.90 & 18.68 & 2.70 \\
\hline ‘Horyzon' & 15.31 & 0.95 & 14.04 & 1.35 & 15.05 & 1.33 \\
\hline 'Mriia' & 19.14 & 1.54 & 17.52 & 1.97 & 21.55 & 2.01 \\
\hline 'Romance' & 19.69 & 1.02 & 20.37 & 1.26 & 21.09 & 1.60 \\
\hline 'Skhidna' & 17.85 & 0.96 & 18.50 & 1.05 & 19.21 & 1.09 \\
\hline 'Kharkivska' & 19.14 & 1.10 & 19.06 & 1.69 & 20.87 & 1.78 \\
\hline $\begin{array}{l}\text { Average content } \\
\text { Średnia }\end{array}$ & 18.66 & 1.23 & 18.30 & 1.68 & 18.91 & 1.72 \\
\hline
\end{tabular}

From the point of vegetative mass productivity and content of isoflavonoids in it, the following soybean varieties of Ukrainian selection had the doubtless advantages - 'Podilska-1', 'Feia', 'Mriia', and 'Skelia'.

It is worth mentioning that both soybean and amaranth vegetative mass were rich in flavonoids $-2.32 \%$ and $1.67 \%$ respectively, which allows to consider both plants as the sources of important polyphenols that might influence the administration of forages by animals and the quality of their production. As a result of the study, soybean of 'Podilska-1' variety was chosen as the most beneficial one in mixed sowing with corn for silage by the content of protein and isoflavonoids.

The increase of fat content in the milk of cows fed by corn-soybean silage instead of corn silage, can be explained by the quantity of flavonoids in corn-soybean silage comparing to the corn silage. Characteristically, the growth of fat concentration in the milk was accompanied by the slight increase of milk production in cows at feeding by corn-soybean silage, which allows the latter to be considered as a better alternative to the corn silage.

It should be mentioned that the corn-soybean silage has shown positive influence on the reproductive function of cows.

\section{CONCLUSIONS}

The results of the experiments carried out allowed identifying and determining the content of such groups of BAC as polysaccharides, polyphenols, flavonoids, isoflavonoids, hydroxycinnamic acids, and vitamin C in 3 Ukrainian soybean varieties - 'Feia', 'Skelia' and 'Podilska-1'. In addition, the steroidal compounds of a new prospective fodder crop - tyfon - were also studied. More detailed study on the content of protein and isoflavonoids in 8 Ukrainian soybean varieties of different stages of vegetation has shown the increase of isoflavonoids content at the complete seed filling phase, while the changes of protein content haven't shown any correlation with the vegetation stage. Using mixed corn-soybean silage in feeding cows appeared to be beneficial for the growth of fat concentration in the milk, as well as the 
reproductive function of cows. Thus, the advisability of the study of BAC, possessing antioxidant, anabolic and other properties, in the green mass of the leading fodder crops was experimentally confirmed.

\section{REFERENCES}

Baraboy V.A. 1984. Plant phenols and human health. Moscov, Science. [in Russian]

Bulanov Yu.B. 1993. Anabolic agents. Tver, TOS "Posrednik". [in Russian]

Dorszewski P. 2011. Pasze wysokobialkowe w zywieniu bydla. Bydlo N2, 16-18.

Jamroz D., Potkanski A. 2004. Żywienie zwierząt i paszoznawstwo. Warszawa, Wydaw. Nauk. PWN. [in Polish]

Koch D.W., Ernst F.C. Jr., Leonard N.R. 1987. Lamb performance on extended-season grazing of tyfon. J. Anim. Sci. 64, 1275-1279.

Kulyk M.F., Zhmud' O.V., Obertiukh Yu.V. 1999. Biologically active compounds of soybean stimulants of synthesis of milk lipids in cows. Bull. Agr. Sci. 37-38. [in Ukrainian]

Levashova O.L. 2002. Agricultural cultures of high-priority - the source of biologically active compounds, in: Proceeding of the All-Ukrainian scientific and practical conference "Pharmacy of XXI century”, Kharkiv, Ukraine, October 23-24, 2002. Kharkiv, National Pharmaceutical University, 166-167. [in Ukrainian]

Taylor W. 2002. Anabolic therapy in modern medicine. North Carolina, McFarland\&Co.

Tsyhanok A.V., Drozdov S.Ye., Kutikov Ye.S., Hnoievyi V.I. 1999. On the effect of synchronizing the terms of transition into the first oestrum in replacement gilts after inclusion amaranth silage into diet. Scientific and technical Bull. Inst. Agric. Animal Biol., Series Physiology and Biochemistry 1(3), 153-154. [in Ukrainian]

Vovk S.O., Pavkovych S.Ya. 2008. Specific features of lipid and fatty-acid nutrition in Ecological, technological, and social-economic aspects of effective usage of AIC material and technical base, in: Proceeding of the International scientific and practical forum. Lviv, Ukraine, September 17-18, 2008, [b.w.], 38-42. [in Ukrainian]

Zinchenko I.G. 2013. The pharmacognostic study of tyfon. Doctoral dissertation. Kharkiv, National Pharmaceutical University.

Abstract. The content of isoflavonoids in the green mass of the leading Ukrainian soybean varieties by the vegetation stages were determined, as well as the presence of a series of phenolic compounds in different vegetative organs of soybean of Podilska-1 variety, which is recommended for combined sowing for silage. The scientific evidence of the influence of these compounds on the butter-fat yielding capacity and reproductive properties of cows, which corresponds with the results of years-long usage of corn-soybean silage as a component of forage mixture for high-producing cows under single-type feeding throughout the year within conditions of a dairy unit with 1050 cows. 